\title{
THE NEW VALUE EXCEPTION TO THE ABSOLUTE PRIORITY \\ RULE AFTER IN RE 203 N. LASALLE STREET PARTNERSHIP. WHAT SHOULD BANKRUPTCY COURTS DO, AND HOW CAN CONGRESS HELP?
}

\author{
HIEU T. HOANG ${ }^{\dagger}$
}

\section{INTRODUCTION}

A company files for bankruptcy when it is no longer viable in its present condition. When a company files for bankruptcy under chapter 7 of the Bankruptcy Code (the "Code"), the company's assets are generally sold off in a piecemeal fashion, and the company is dissolved.' When a company files for bankruptcy under chapter 11 of the Code, however, the company is not liquidated but instead reorganized. ${ }^{2}$ Some form of payment to the creditors satisfies claims against the company, most debts are discharged, and the company continues operating in essentially the same business, usually with the same management. ${ }^{3}$ For creditors, the difference between these two forms of bankruptcy is that under chapter 7, the creditors will receive the cash value of the company's assets, while under chapter 11 , the creditors will likely retain the company.

The reason that creditors may end up owning the company under chapter 11 is the absolute priority rule, enunciated in 11 U.S.C. $\$ 1129$ (b) (2) (B) (ii), which generally states that no junior creditors or

† A.B., Stanford University, 1997; J.D. Candidate, University of Pennsylvania Law School, 2001. I would like to thank my sister, Hoa T.T. Hoang, Esq., for suggesting this topic. I also owe a great deal of gratitude to Professor Kathryn Heidt, Justin DeSpirito, Adam McLain, and the associate editors of the University of Pennsylvania Law Review for their comments, suggestions, and corrections. Any remaining errors are my own.

i 11 U.S.C. $\$ \$ 701-766$ (1994).

Id. $\$ \$ 1101-1174$. However, a reorganization plan can include a liquidation of assets. See, e.g., id. $\$ 1174$ (allowing for the liquidation of railroads if a reorganization plan has not been adopted).

See id. $\$ 1141$ (d)(3)(B) (stating that claims against a debtor will not be discharged if the debtor does not "engage in business after consummation of the plan"). While the Code does not require that the reorganized company operate in the same business that it did before it filed for relief, it is highly unlikely that the company will be operating in a totally different line of business because the company will be using the same assets that it possessed before bankruptcy. 
interest holders, such as the owners of the indebted company, will retain any interest, which includes ownership in the reorganized company, before claims of senior creditors are satisfied. Since many debtors cannot satisfy the claims of their creditors, the creditors would usually end up owning the company. ${ }^{4}$ Most creditors, however, do not want to end up running the reorganized company, ${ }^{5}$ so they usually negotiate with the debtor-often before the debtor files for bankruptcy-to come up with a different solution.

Debtors can thus retain ownership and control of the reorganized company if the creditors consent. ${ }^{6}$ Even if a class of creditors does not consent, a debtor can still retain ownership of the company if a plan of reorganization giving ownership in the company to old equity holders is imposed upon, or "crammed down" on, the creditors." Such a plan of reorganization is called a "new value" plan. The name comes from the "new value exception," a judicially created doctrine that allows old equity holders to retain ownership in the company despite the absolute priority rule. ${ }^{8}$ After Norwest Bank Worthington v. Ahlers, however, there was debate regarding whether a plan using the new value exception would be confirmable." In Bank of America $\mathrm{Na}$ -

${ }^{4}$ Why then do the creditors not sell off the newly acquired company? It would not make sense for the creditors to sell the reorganized company if the company is worth more as a going concern than if it is liquidated. The difference between these two values is the going concern premium. While the going concern premium is generally positive, this is not necessarily true. For example, if a company is sold as a whole, there may be no premium above the liquidation price. For a discussion on the analytic confusion between going concern and liquidation values, see John D. Ayer, Rethinking $A b$ solute Priority After Ahlers, 87 MrCH. L. REV. 963, 1000 n.198 (1989). Furthermore, the Code likely prohibits such subsequent liquidation. See 11 U.S.C. $\$ 1129$ (a)(11) (requiring that confirmation of the plan "is not likely to be followed by ... liquidation, or the need for further financial reorganization").

${ }^{5}$ Creditors are in the business of lending money, not running businesses.

${ }^{6}$ See 11 U.S.C. $\$ 1129(a)(8)$ (A) (permitting confirmation of a plan of reorganization if creditors accept the plan).

${ }^{7}$ See id. $\$ 1129$ (b) (1) (permitting confirmation of a plan of reorganization despite a dissenting class of claim holders if certain enumerated requirements, including the absolute priority rule, are fulfilled). This Comment will not deal with the classification of claims. For an example of the problems that may arise when classifying claims in chapter 11, see Phoenix Mutual Life Insurance Co. v. Greystone III Joint Venture, 948 F.2d 134 (5th Cir. 1992). It is sufficient for the reader to understand that only similarly situated creditors can be placed in the same class. Thus, there must be at least two classes of claim holders-creditors and equity holders.

${ }^{8}$ See Bank of Am. Nat'l Trust \& Savs. Ass'n v. 203 N. LaSalle St. P'ship (In re 203 N. LaSalle St. P'ship), 526 U.S. 434, 442-43 (1999) [hereinafter 203 N. LaSalle] (explaining the new value exception).

485 U.S. 197, 202-03 (1988) (noting that the existence of the new value exception to the absolute priority rule after the codification of the rule in chapter 11 was 
tional Trust $\mathcal{F}^{2}$ Savings Ass'n v. 203 N. LaSalle Street Partnership (In re 203 N. LaSalle Street Partnership) (hereinafter 203 N. LaSalle), the Supreme Court declined to address the issue of whether the new value exception existed. ${ }^{10}$ The Court, however, did reject the new value plan at issue, although it suggested that a new value plan that allowed for a market valuation would be confirmable. ${ }^{11}$

This Comment explores two methods that could satisfy the $203 \mathrm{~N}$. LaSalle Court and still permit the debtor to file a new value plan. Part I examines the origin of the absolute priority rule from its beginnings in railroad bankruptcy to its current codification in the Code. ${ }^{12}$ Part II traces the historical development of the new value exception from its origins in Case v. Los Angeles Lumber Products $\mathrm{Co}^{13}$ to its present existence after 203 N. LaSalle.

Part III examines how the new requirement imposed by $203 \mathrm{~N}$. LaSalle could be satisfied either by allowing any party to submit competing reorganization plans or by allowing any party to make bids for the equity interest in the reorganized company. It explores how each process could occur under the Code and which method is preferable. Drawing upon auction theory, Part III shows that the two methods likely will yield the same result and suffer from many of the same weaknesses. The competing bids method is preferable, however, because it allows creditors to distinguish easily which reorganization plan will pay them more.

Part IV examines two considerations that would eliminate the need for a debtor to use either proposed method in filing a new value plan: (1) exclusion of single-asset real estate debtors from the use of the new value exception, and (2) equality of tax treatment for debtors filing under chapter 7 and chapter 11 of the Code. It argues that the Internal Revenue Code should be amended to reduce the incentives of single-asset debtors to file for bankruptcy under chapter 11.

Finally, this Comment argues that, barring amendment of the Internal Revenue Code, the bankruptcy court should apply the compet-

debatable).

I" 526 U.S. 434.

"See id. at 458 ("[P]lans providing junior interest holders with exclusive opportunities free from competition and without benefit of market valuation fall within the prohibition of [the absolute priority rule].").

${ }^{12}$ This Comment does not analyze the absolute priority rule under a constitutional approach but rather under a statutory approach. See Ayer, supra note 4, at 968 (arguing that there are two laws of absolute priority, one based on the Code and the other on the Due Process Clause of the Fifth Amendment).

${ }^{11} 308$ U.S. 106 (1939). 
ing bids option to ensure that new value plans meet the requirements of 203 N. LaSalle.

\section{A HISTORICAL REVIEW OF THE NEW VALUE EXCEPTION}

\section{A. Chapter 11 of the Code}

One of the options available to debtors who are facing financial distress is bankruptcy. ${ }^{14}$ Under $\$ 301$ of the Code, a debtor can voluntarily commence a bankruptcy case by filing a petition under a bankruptcy chapter allowable to that debtor. ${ }^{15}$ Chapter 11 is available to any debtor that wishes to reorganize its finances. ${ }^{16}$ After successfully filing the petition, ${ }^{17}$ the debtor has an exclusive period of 120 days to propose a reorganization plan. ${ }^{18}$ A reorganization plan may be approved by all classes of creditors, in which case the bankruptcy court will likely confirm the plan. ${ }^{19}$ Sometimes, one or more creditors may

${ }^{14}$ See 11 U.S.C. $\$ 109$ (1994) (defining who may be a debtor for the purposes of the Code). Section 109 (a) provides that only a United States resident may be a debtor under the Code. Subsequent subsections define the requirements to be a debtor under chapters $7,9,11,12$, and 13 . Id. $\$ 109$.

${ }^{15}$ Id. $\$ 301$ (setting forth the process for commencing a voluntary case of bankruptcy). Most debtors file for relief under chapter 7 or chapter 11 because more individuals are allowed to file under those chapters according to $\$ 109$ of the Code. Under chapter 7 , the debtor liquidates its assets and distributes them among its creditors. Id. $\$ 706$ (stating that the property of the debtor will be collected and reduced into money). Under chapter 11, the debtor proposes to reorganize its finances and gradually pay its creditors. Id. $\S 1123$ (requiring that a plan of reorganization propose how the claims against and interests in the debtor be treated).

${ }^{16}$ Chapter 11 is available only to "a person that may be a debtor under chapter 7 of [the Code], except [for] a stockbroker or a commodity broker [or] a railroad." Id. $\S 109$ (d). "A person may be a debtor under chapter $7 \ldots$ only if [a] person" is not a railroad or certain financial or insurance institutions. Id. $\$ 109(\mathrm{~b})$. In Toibb v. Radloff. 501 U.S. 157 (1991), the Court held that chapter 11 is not limited to business debtors.

${ }^{17}$ Among the obstacles to a successful petition are conversion or dismissal by the bankruptcy court under $\$ 1112$ of the Code. See 11 U.S.C. $\$ 1112$ (providing that the bankruptcy court can convert a case into one under another chapter of the Code if certain requirements are met, or dismiss a case if it is in the best interests of the creditors and the estate). The estate referred to in $\$ 1112$ is the bankruptcy estate, which consists of "all legal or equitable interests of the debtor in property." Id. $\$ 541$ (a) (1). Once the debtor files a petition, there is an automatic stay imposed on nearly all entities, preventing such entities from most collection efforts against the debtor. See id. $\$ 362$ (a) (preventing listed creditors from engaging in listed activities during stay). For a more detailed examination of the workings of the bankruptcy system, see PETER A. ALCES \& MARGARET HOWARD, BANKRUPTCY: CASES AND MATERLALS 22-109 (1995).

${ }^{18}$ See 11 U.S.C. $\$ 1121$ (b) (providing that the debtor "may file a plan until after 120 days after the date of order of relief").

${ }^{19}$ See id. $\$ 1129$ (a) (setting forth the requirements for confirmation of a reorgani- 
object to the proposed plan. In these situations, the debtor may modify the plan, ${ }^{2 \prime \prime}$ submit another reorganization plan, ${ }^{21}$ or petition the bankruptcy court to "cram down" ${ }^{22}$ the plan on all of the creditors. ${ }^{23}$

To protect the creditors in the event of a cram down, the court will confirm a reorganization plan only if it meets certain requirements that are laid out in the Code. The court may confirm a plan that meets all of the requirements of $\$ 1129$ (a), or all of the requirements of $\$ 1129$ (a) except for (a) (8), which requires acceptance by all impaired classes. ${ }^{24}$ In the latter case, the plan must also satisfy all of the requirements of $\$ 1129(\mathrm{~b})$. In pertinent parts, $\S 1129(\mathrm{~b})$ provides that:

(1) $[\mathrm{T}]$ he court ... shall confirm the plan ... if the plan ... is fair and equitable....

zation plan, including acceptance). The Code provides that a proposed plan must have the acceptance of all classes of impaired creditors. An impaired class generally is one in which the constituent claimants have not retained all their prebankruptcy rights. See id. \$1124 (defining impairment). An impaired class of claims or interests has accepted a plan if more than one-half of all claimants in the class, holding more than two-thirds of the amount of debt of the class, accept the plan. See id. \$1126(c), (d) (defining acceptance of a proposed plan). Another requirement for confirmation of a plan is that the creditors receive as much under the chapter 11 plan as they would have received under chapter 7. Id. $\$ 1129$ (a)(7)(A) (ii). This is called the "best interests" test. ALCES \& HOWARD, supra note 17, at 656 . "Subsection (a) (7) requires the court to conduct a hypothetical liquidation analysis and to compare the dissenter's hypothetical dividend with the plan's proposed payment." Id.

The court generally looks to the creditors to ensure that the plan is fair. See 11 U.S.C. app. Rule 3018(a) (allowing equity security holders or creditors to accept or reject a plan). The creditors likewise participate in the negotiation of any reorganization plan through the creditors' committee. See 11 U.S.C. $\$ 1102$ (a)(1) ("[A]s soon as practical after the order for relief under chapter 11 of [the Code], the United States Trustee shall appoint a committee of creditors holding unsecured claims and may appoint additional committees of creditors or of equity security holders as the United States Trustee deems appropriate."). The United States Trustee represents the interest of the United States in all bankruptcy proceedings, and "may raise and may appear and be heard on any issue in any case or proceeding under [the bankruptcy code] but may not file a plan." Id. $\$ 307$.

:"1) See 11 U.S.C. $\$ 1127$ (laying out the requirement for the modification of a plan).

: See id. $\$ 1121$ (c) (3) (allowing the debtor to file another plan if "the debtor has not filed a plan that has been accepted").

"22 "Cram down" refers to the process of forcing nonconsenting creditors to accept a reorganization plan. The plan is crammed down the creditor's throat. See generally David G. Epstein, Don't Go and Do Something Rash About Cram Down Interest Rates, 49 ALA. L. REV. 435, 437 (1998) (describing the cram down process and noting that the Code does not use the term "cram down").

S. See 11 U.S.C. $\$ 1129$ (b) (allowing confirmation of a plan despite a class of objecting creditors).

$: 24$ See id. $\$ 1129$ (a) (outlining all of the requirements that must be met before the court can confirm a plan). 
(2) ... [T] $]$ he condition that a plan be fair and equitable ... includes the following requirements:

$\cdots \cdots$

(B) With respect to a class of unsecured claims-

(i) the plan provides that each holder of a claim of such class receive or retain on account of such claim property of a value, as of the effective date of the plan, equal to the allowed amount of such claim; or

(ii) the holder of any claim or interest that is junior to the claims of such class will not receive or retain under the plan on account of such junior claim or interest any property. ${ }^{25}$

Thus, a plan can be confirmed under $\S 1129$ (b)(2)(B)(i) despite the objections of a class of creditors if the class of creditors would receive property equal to the amount of their allowed claims. Since a debtor filing for bankruptcy tends to be insolvent, the requirement of subsection (b) (2) (B) (i) is rarely satisfied. ${ }^{26}$ Rather, most plans that are confirmed despite an objecting creditor satisfy the requirement of subsection (b) (2) (B) (ii) instead. Subsection (b) (2) (B) (ii) provides that a holder of a senior claim, such as an unsecured creditor with a deficiency claim, must be paid before a holder of a junior claim or interest, such as an equity holder, is paid. "[This] latter condition is the core of what is known as the 'absolute priority rule.",27

\section{B. The Absolute Priority Rule}

The absolute priority rule is a legal rule that requires a bankrupt firm to pay off its creditors in order of the claim holders' or interest holders' priority status. Under this rule, all creditors must be paid off before an equity holder can receive any property from the company.

${ }^{25} I d . \$ 1129(\mathrm{~b})$. The plan must still satisfy all of the other requirements laid down in $\S 1129$ (a). See id. $\S 1129$ (b) (requiring that "all of the applicable requirements of subsection (a) of [11 U.S.C. $\$ 1129$ ]" be met for a plan to be imposed upon an objecting creditor during the cram down process). Thus, a plan that is imposed upon an objecting party must also ensure that the creditors receive as much as they would have under the chapter 7 liquidation process. Id. $\$ 1129(\mathrm{a})(7)(\mathrm{A})$ (ii). For a more detailed discussion of cram down in bankruptcy, see Kenneth N. Klee, All You Ever Wanted to Know About Cram Down Under the New Bankruptcy Code, 53 AM. BANKR. L.J. 133 (1979).

${ }^{26}$ Debtors who file for bankruptcy do not have to be insolvent. See In re JohnsManville Corp., 36 B.R. 727, 732 (Bankr. S.D.N.Y. 1984) ("[W]ith specific regard to Chapter 11, the Code eliminates the requirement... that the debtor be insolvent ....". 
The absolute priority rule was the response to the perceived abuses of the railway receivership system during the beginning of the nineteenth century. ${ }^{28}$

Reorganization via the railway receivership system was "carefully orchestrated." Typically, a creditor petitioned a court of equity to appoint a receiver to take control of the debtor's assets and sell them for the benefit of the creditors. ${ }^{30}$ The receiver then took title to all of the assets, and individual creditors could no longer levy on the railroad's assets. ${ }^{\text {.1 }}$ Rather, the various creditors would meet and agree upon a plan of reorganization. ${ }^{32}$ The reorganization plan created and empowered the reorganization committee and specified how much a creditor would receive after the reorganization process if she transferred her claims against the debtor to the committee. ${ }^{33}$

With the plan in place, the receiver would then trigger a foreclosure sale and the reorganization committee would be the winning bidder at the foreclosure sale. ${ }^{34}$ Next, the proceeds of the sale were distributed to the creditors in order of priority. This generally meant that the unsecured creditors were not paid. ${ }^{35}$ Then, the reorganization committee would form a new corporation and transfer the assets from the old corporation to the new corporation. Those creditors who had transferred their claims to the committee would receive claims against the new corporation. ${ }^{36}$ Those creditors who only had claims against the old corporation were out of luck since the old corporation would be dissolved. ${ }^{37}$

This process was vulnerable to several kinds of abuses. First, the price that the committee would bid for the assets of the old firm was

2* For a discussion on why the railway receivership system became the preferred method of dealing with bankrupt railway companies, see Bruce A. Markell, Owmers, Auctions, and Absolute Priority in Bankruptcy Reorganizations, 44 STAN. L. REv. 69, 74-77 (1991) (reciting the early history of the absolute priority rule).

Id. at 75 .

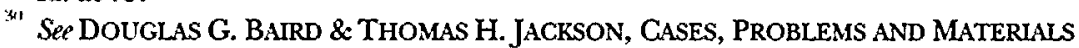
ON BANKRUPTCY 961 (2d ed. 1990) (discussing the receivership process).

${ }^{31} I d$.

32 Id.

is Id.

Id. at $961-62$.

35 See id. at 963 (noting that the proceeds of the sale would not be distributed to the unsecured creditors and shareholders because the "sale price was not enough to pay those with the highest priority in full").

Id. at 962.

${ }^{37}$ See id. at 963 (stating that since the old corporation no longer exists, "all claims against it are worthless"). 
artificially low since the committee was generally the only bidder at the foreclosure sale. ${ }^{38}$ To remedy this problem, there was a judicially imposed "upset price.", The upset price was the "minimum price that the reorganization committee would have to bid at the foreclosure sale to acquire the assets of the railroad." ${ }^{, 40}$ As with any other price control, there were some problems. ${ }^{41}$ If the upset price were too high, no one would bid for the assets since the assets were worth less than the price. The reorganization committee would not be able to bid for the assets since they would not be able to raise the money for such an economically irrational bid. In practice, most judges tended to set the upset price low to ensure that the committee could purchase the railroad assets. ${ }^{42}$ This led to the creditors receiving less than they would have received if no upset price had been set.

A more problematic development was that the court-appointed receiver was usually the old management of the railroad company who had led the company into bankruptcy. ${ }^{43}$ Old management would transfer its equity interest in the railroad to the reorganization committee in return for equity interests in the new organization. ${ }^{44}$ Typically, old management also would be the management of the new corporation. Thus, foreclosure of the railroad by the equity receivership sometimes led to the same shareholders owning the same company that was no longer subject to the claims of the unsecured creditors. $^{45}$

As a result, unsecured creditors often challenged reorganizations via railway receiverships. ${ }^{46}$ In Northern Pacific Railway Co. v. Boyd, the

The committee was the only bidder at the foreclosure sale because there were few companies that had the resources to purchase an insolvent railroad company, see Markell, supra note 28, at 74, and the railroad's assets, which consisted of rights of way over narrow strips of land, and assorted rails, wooden ties, and bridges, had little scrap value, see BAIRD \& JACKSON, supra note 30, at 960 .

${ }^{39}$ BAIRD \& JACKSON, supra note 30 , at 964 .

${ }^{40}$ Id.

${ }^{41}$ For a more detailed criticism of price control in the context of minimum wages, SEe HENRY N. BUTLER, ECONOMIC ANALYSIS FOR LAWYERS 477-79 (1998).

${ }^{42}$ See BAIRD \& JACKSON, supra note 30 , at 964 (discussing the problems with the use of an upset price).

${ }^{43}$ There were several valid reasons for including old management in the process. Old management generally had expertise in managing operations and was "often willing to contribute new cash to save their investment." Markell, supra note 28, at 76 .

See id. (noting that an alliance arose between bondholders and stockholders in which the "reorganization plan would often provide for the new entity to issue securities to the old equity holders upon contribution of a stated price").

${ }_{45}^{4}$ See BAIRD \& JACKSON, supra note 30 , at 967.

${ }^{46}$ The foreclosure of the railroad by the equity receiver discharged both the se- 
Court held that the previously detailed reorganization process violates the "fixed principle" that "property in the hands of the former owners, under a new charter, was as much subject to any existing liability as that of a defendant who buys his own property at a tax sale." 7

Boyd concerned a reorganization plan "under which all of the stocks and bonds of the Railroad were to be transferred to a new company ... which was to purchase the property of the Railroad," and issue new stock to repay liabilities in exchange for the interests in the old company. ${ }^{48}$ Joseph $\mathrm{H}$. Boyd had a judgment against a subsidiary of the old Northern Pacific Railroad Company, but could not levy because all of the assets of the subsidiary had been sold in foreclosure. ${ }^{* 9}$ Boyd claimed that the new company was liable for the judgment and the Court agreed. ${ }^{5 \%}$

The Court held that "such a sale would be void, even in the absence of fraud." The Court stated that "[a]ny arrangement of the parties by which the subordinate rights and interests of the stockholders are attempted to be secured at the expense of the prior rights of either class of creditors comes within judicial denunciation." ${ }^{52}$ Thus, the Court found that the new corporation was still liable to Boyd for the judgment that Boyd had against the old corporation's subsidiary.

The Court tempered this holding by stating that:

[the unsecured creditor's] interest can be preserved by the issuance, on equitable terms, of income bonds or preferred stock. If he declines a fair offer he is left to protect himself as any other creditor of a judgment debtor, and, having refused to come into a just reorganization, [cannot] attack it. If, however, no such tender was made and kept good he retains

cured and unsecured debt. See Markell, supra note 28, at 76 (noting that unsecured creditors "were squeezed out and given nothing"). For a discussion on why the unsecured creditors challenged this arrangement under fraudulent transfer law instead of under some other state law theory, see $i d$. at 76-77.

${ }^{47} 228$ U.S. 482, 507 (1913).

Id . at $488-89$.

4: See id. at 498-501 (recounting the facts in the case). Since Boyd could not levy against the assets, his judgment did not become a lien, and therefore had the same priority as an unsecured claim. See U.C.C. \$ 9-301(1) (1994) (stating that an unperfected security interest is subordinate to the claim of a lien creditor; also stating, by negative implication, that a judgment without a levy does not have priority over an unsecured claim); $i d$. $\$ 9-301$ (3) (defining a lien creditor as one who acquires a lien through, among other means, a writ of levy).

51. See Boyd, 228 U.S. at 502 ("[W] hen [Boyd] appeared and established his debt the subordinate interest of the old stockholders would still be subject to his claim in the hands of the reorganized company.").

${ }^{51}$ Id. at 504-05 (citing Louisville Trust Co. v. Louisville, New Albany \& Chi. Ry. Co., 174 U.S. 674 (1899)).

Id. at 505 (quoting Louisville Trust Co., 174 U.S. at 684). 
the right to subject the interest of the old stockholders in the property to the payment of his debt. If their interest is valueless, he gets nothing. If it be valuable, he ... [receives as much as he deserves].

Thus, if the debtor gives a fair offer to the unsecured creditor, the debtor can retain an equity interest in the new corporation.

The Court, however, failed to enunciate any standard for what would constitute a fair offer. Commentators came in to fill the gap, and two different theories of fair offers were developed. ${ }^{54}$ The first theory, known as the theory of "relative priority," allowed equity holders to participate "only if the projected earnings of the reorganized company exceeded [the] pre-receivership debt., ${ }^{, 5}$ The idea was that the new infusion of cash by the shareholders led to the excess earnings. The second theory, known as "absolute priority," allowed junior claim holders to participate only "when the reorganization plan allocated values in accordance" with "the full amount of a creditor's state law entitlement upon liquidation." ${ }^{, 56}$ Thus, equity holders could participate only if the claims of creditors were satisfied first, since equity holders have a lower priority than even unsecured creditors. ${ }^{57}$

Although Congress codified most of the features of equity receivership in 1922 and 1934 by adding sections 77 and 77B to the Bankruptcy Act of 1898, it merely required a judicial finding that proposed reorganization plans be "fair and equitable." Unfortunately, "fair and equitable" was broadly interpreted to sustain both theories of "fair offer." ${ }^{.59}$ The Court finally determined which theory of "fair offer" was correct in Case v. Los Angeles Lumber Products Co. ${ }^{60}$

Case concerned a reorganization plan which allowed some of the old stockholders, who had contributed their "financial standing and influence in the community" to the new organization, to receive an interest in the new corporation even though the old firm's mortgage

53 Id. at 508.

${ }^{54}$ See Markell, supra note 28, at 82 ("After weak attempts by the Court to give meaning to the term, two different conceptions of fair offers eventually arose.").

${ }^{55}$ Id.

${ }^{56} I d$.

57 In fact, shareholders have the last or residual claim on the company. See, e.g., DEL. CODE ANN. tit. 8, $\$ 281$ (a) (Supp. 1998) (stating that upon dissolution of a corporation, all assets are first distributed to pay claims and obligations of the corporation, and any remaining assets are distributed to the stockholders).

${ }^{58}$ Markell, supra note 28, at 83.

${ }^{59}$ See id. (" $[\mathrm{P}]$ roponents of relative priority believed the language of the statute allowed business as usual. ... [O] ther creditors did not share this view.").

${ }^{60} 308$ U.S. 106 (1939). 
had not been satisfied. ${ }^{61}$ The proposed plan would have satisfied the relative priority standard, but not the absolute priority standard. ${ }^{62}$ The Court rejected the plan, summarily holding that the "rule of absolute or full priority" applied to the "fair and equitable" standard enunciated in section $77 \mathrm{~B} .^{63}$ Thus, the plan could not be confirmed despite the approval by over $90 \%$ of bondholders ${ }^{64}$ because the stockholders' retention of an interest in the company when creditors were not paid in full violated the general rule of absolute priority. ${ }^{65}$ The absolute priority rule set forth in Case has been codified in $\$ 1129(\mathrm{~b})(2)(\mathrm{B})(\mathrm{ii}) .^{6 \sigma}$

\section{New Value Plans in Ghapter 11 BankRuptcy}

\section{A. The New Value Exception}

Besides determining that the fair and equitable standard required the rule of absolute priority, the Court in Case stated that:

It is, of course, clear that there are circumstances under which stockholders may participate in a plan of reorganization of an insolvent debtor....

In view of these considerations we believe that to accord "the creditor

"1. Id. at 109-20, 122-23 (finding that the total value of the debtor's assets was $\$ 830,000$ and the first lien mortgage was $\$ 3,807,071.88$; rejecting the contention that contribution of intangibles satisfied the new value exception).

iit See id. at 119-20 (noting that the stock issuance preserved relative priorities, but that the amount of the debtor's assets in comparison to the first mortgage amount necessitated the ultimate failure of absolute priority); Markell, supra note 28, at 84 (same). The plan preserved relative priority because the stockholders kept $23 \%$ of the corporation, while the assets of the company were approximately $25 \%$ of the debt. The creditors would retain a share of the company approximately worth the relative amount of their claims. The plan failed absolute priority because shareholders retained an interest in the company, despite the failure to pay the creditors in full.

${ }^{63}$ Case, 308 U.S. at 115-16. For an argument that the holding had no basis in case law or in the plain language of section 77B of the Bankruptcy Act, see Ayer, supra note 4 , at $974-75$.

${ }^{64}$ Case, 308 U.S. at 115.

${ }^{65}$ See id. at 119-20 (discussing the priority rights of creditors in relation to those of stockholders).

${ }^{\circ 6}$ See 203 N. LaSalle, 526 U.S. at $442-43$ (noting that subsection (b) (2) (B) (ii) is the core of the absolute priority rule). The absolute priority rule, however, applies only if there is a class of dissenting creditors. The current Code does not require all creditors to accept the plan before the absolute priority rule must be met. Rather, a class of creditors is considered to have accepted a plan if it has been accepted by creditors that hold more than one-half in number of allowed claims of that class and at least twothirds of the total dollar amount of claims within that class. 11 U.S.C. $\$ 1126(\mathrm{c})$ (1994). 
his full right of priority against the corporate assets" where the debtor is insolvent, the stockholder's participation must be based on a contribution in money or in money's worth, reasonably equivalent in view of all the circumstances to the participation of the stockholder. ${ }^{67}$

This dictum formed the basis for the new value exception. ${ }^{\text {\& }}$ Under the new value exception, equity holders in the company could receive property from the bankrupt firm even though all senior claim holders had not been paid in full.

Case also provided a test for when to apply the new value exception: when (1) there is a contribution in money or money's worth, and (2) the contribution is reasonably equivalent to the participation afforded. ${ }^{69}$ The plan at issue in Case failed to satisfy this test because the contribution was not in money or money's worth, but rather in the intangibles of "financial standing and influence in the community."

Case was decided in 1939, well before Congress passed the Bankruptcy Act of 1978. The Act did not mention the new value exception. Thus, it was possible to infer that the new value exception no longer existed. $^{71}$ Since Congress did not affirmatively repudiate the new value exception, however, it was also possible to argue that the doctrine continued to exist. ${ }^{72}$ The Supreme Court had a perfect opportunity to address this question in Norwest Bank Worthington v. Ahlers. ${ }^{73}$

Ahlers involved a failing family farm that owed over one million dollars to Norwest Bank Worthington. ${ }^{74}$ The bank moved for foreclosure upon default, but the debtor filed a petition for relief under

${ }^{67}$ Case, 308 U.S. at 121-22 (quoting Kansas City Terminal Ry. Co. v. Central Union Trust Co., 271 U.S. 445, 456 (1926)).

"So Some commentators have called the new value exception the new value "corollary." The Supreme Court, however, has used the term new value "exception." Norwest Bank Worthington v. Ahlers, 485 U.S. 197, 203 n.3 (1988).

${ }^{69}$ Case, 308 U.S. at 122. Some courts have also concluded that there is a necessity standard-that the infusion of new capital be necessary. See, e.g., Coltex Loop Cent. Three Partners v. BT/SAP Pool C Assocs. (In re Coltex Loop Cent. Three Partners), 138 F.3d 39, 45 (2d Cir. 1998) (finding that a new value exception, if it existed, required that there be necessity).

${ }^{70}$ Case, 308 U.S. at 122.

${ }^{7} \mathrm{See}$ Brief for the United States as Amicus Curiae Supporting Petitioners at 22, Ahlers (No. 86-958), microformed on U.S. Supreme Court Records and Briefs (Microform, Inc.) (arguing that because Congress failed to include any exception to the absolute priority rule, Congress "had dropped the infusion-of-new-capital exception to the absolute priority rule").

${ }^{72}$ See Markell, supra note 28, at 103 (arguing that Congress did not reject the new value exception when it passed the Bankruptcy Act of 1978).

${ }^{73} 485$ U.S. 197.

${ }^{74}$ Id. at $199-200$. 
chapter $11 .^{73}$ Under the reorganization plan, the debtors would retain their equity interest in the farm by contributing "labor, experience, and expertise." ${ }^{, 6}$ The Court held that this was a violation of the absolute priority rule because a promise of future labor is an intangible asset that is not an "adequate contribution to escape the absolute priority rule." The Court stated: "[W]e simply conclude that even if an 'infusion of money-or-money's-worth' exception to the absolute priority rule has survived the enactment of $\S 1129$ (b), respondents' proposed contribution to the reorganization plan is inadequate to gain the benefit of this exception."

Thus, read narrowly, Ahlers merely upholds the absolute priority rule. Unfortunately, Ahlers also introduced uncertainty into bankruptcy law when it left open the question of whether the new value exception survived the Bankruptcy Act of $1978 .^{79}$ The Court seemed to agree that the new value exception did not survive the Act when it called the exception debatable.

Despite the Court's contention in Ahlers that it left unanswered the question of the future viability of the new value exception, ${ }^{81}$ some courts have taken the language in Ahlers as a call for a reexamination of the new value exception. ${ }^{82}$ Because the courts of appeals have split on whether the new value exception has survived the enactment of the Bankruptcy Act of $1978,{ }^{88}$ it appeared necessary for the Court finally to

${ }^{75}$ Id. at 200. In 1978, Congress passed the Bankruptcy Act, which was the predecessor to the current Code, and established the various chapters under which a debtor could file for bankruptcy. The absolute priority rule was codified in 11 U.S.C. $\$$ 1129 (b) (2) (B) (ii) (1994). For a detailed examination of the many other aspects of the fair and equitable rule that were not codified in the Bankruptcy Act of 1978, see Kenneth N. Klee, Cram Down II, 64 AM. BANKR. L.J. 229 (1990).

si Ahlers, 485 U.S. at 203.

${ }^{77}$ Id. at 205.

${ }^{78}$ Id. at 204 n.3 (citations omitted).

"Id. at 203. Besides introducing uncertainty, the Ahlers decision also made erroneous statements concerning the absolute priority rule and the new value exception. See Markell, supra note 28, at 86 n.113.

Ahlers, 485 U.S. at 205.

${ }^{* 1}$ See id. at 203-04 n.3 ("[O]ur decision today should not be taken as any comment on the continuing vitality of the Los Angeles Lumber exception-a question which has divided the lower courts since the passage of the Code in 1978.").

${ }^{\times 2}$ See Markell, supra note 28, at $95 \mathrm{nn} .163-66$ (discussing cases that have rejected the new value exception, declined to find that Congress discarded the new value exception, or attempted to refine the absolute priority rule).

Sise Bank of Am. Nat'I Trust \& Savs. Ass'n v. 203 N. LaSalle St. P'ship (In re 203 N. LaSalle St. P'ship), 126 F.3d 955, 958 (7th Cir. 1997) (approving a bankruptcy reorganization plan granting the debtor an exclusive opportunity to propose a new value plan which allowed the former equity holders to retain equity interests in the partner- 
answer the question. In $203 \mathrm{~N}$. LaSalle, however, the Court again refrained from addressing the viability of the new value exception. ${ }^{84}$

\section{B. 203 N. LaSalle}

In 203 N. LaSalle, the Bank of America National Trust and Savings Association (the "Bank") was the major creditor of the 203 North LaSalle Street Partnership (the "Partnership" or "Debtor"), an Illinois real estate limited partnership. ${ }^{85}$ The Bank had lent the Partnership $\$ 93$ million, secured by a nonrecourse first mortgage on the Debtor's principal asset, fifteen floors of an office building in downtown Chicago. $^{86}$ When the Debtor defaulted, the Bank moved to foreclose. The Debtor responded by filing for relief under chapter 11 of the Code. $^{87}$

During its 120-day exclusivity period, the Debtor proposed a reorganization plan under which certain partners would contribute $\$ 6.125$ million in new capital over five years in exchange for the Partnership's entire ownership of the reorganized debtor. ${ }^{88}$ In addition, the Bank's $\$ 54.5$ million secured claim would be paid in full. ${ }^{89}$ The Bank's unsecured claim of $\$ 38.5$ million would be discharged for an estimated $16 \%$ of its present value, and the remaining unsecured claims of $\$ 90,000$ held by outside trade creditors would be paid in full without

ship despite failing to satisfy the claims of senior creditors), rev'd, 526 U.S. 434 (1999); Bonner Mall P'ship v. United States Bancorp Mortgage Co., 2 F.3d 899, 910-17 (9th Cir. 1993) (same). But see Coltex Loop Cent. Three Partners v. BT/SAP Pool C Assocs. (In re Coltex Loop Cent. Three Partners), 138 F.3d 39, $44-45$ (2d Cir. 1998) (rejecting a new value plan as violating the absolute priority rule because the plan prevented noninsider creditors from being paid in full, and stating that even if the new value exception existed, the plan failed to satisfy the "necessity" requirement for new value plans); Travelers Insur. Co. v. Bryson Props., XVIII (In re Bryson Props., XVIII), 961 F.2d 496, 504 (4th Cir. 1992) (rejecting a new value plan because, assuming that the new value exception existed, the partners' exclusive right to contribute constitutes "property" under $\$ 1129$ (b) (2) (B) (ii), which prohibits junior creditors from receiving property before senior creditors).

${ }^{84}$ See 526 U.S. at 454 ("Which of these positions [whether the new value exception exists or not] is ultimately entitled to prevail is not to be decided here ....").

${ }^{85}$ Id. at $437-41$.

${ }^{86}$ Id. at 438 .

${ }^{87} I d$.

${ }^{88}$ Id. at 440 .

${ }^{89}$ The bankruptcy court valued the assets at $\$ 54.5$ million using the discounted cash flow method. See In re 203 N. LaSalle St. Ltd. P'ship, 190 B.R. 567, 574-76 (Bankr. N.D. Ill. 1995) ("The court accepts the discounted cash flow method of valuation."), aff'd, 126 F.3d 955 (7th Cir. 1997), rev'd, 526 U.S. 434 (1999). This method is considered the most accurate method for evaluating rental value. See id. (noting that the experts for both parties agreed on the discounted cash flow method). 
interest on the effective date of the plan..$^{90}$ Although the Bank objected to the plan, the bankruptcy court considered it fair and equitable and thus "crammed down" the plan on the Bank."

The Seventh Circuit affirmed the bankruptcy court decision. ${ }^{92}$ The Seventh Circuit held that the plan satisfied the absolute priority rule because:

[W] hen an old equity holder retains an equity interest in the reorganized debtor by meeting the requirements of the new value corollary, he is not receiving or retaining that interest 'on account of his prior [junior claim]. Rather, he is allowed to participate in the reorganized entity 'on account of a new, substantial, necessary and fair infusion of capital.

The Supreme Court reversed and remanded. ${ }^{9 *}$

In a decision written by Justice Souter, the Court found sufficient ambiguity in the statutory text of $\$ 1129$ (b) to allow for "the possibility apparent in the statutory text, that the absolute priority rule now on the books as [11 U.S.C. $\S 1129$ (b) (2)(B) (ii)] may carry a new value corollary." could have survived the enactment of the Bankruptcy Act in $1978 .^{96}$ As a result, debtors can continue to propose new value plans and point to this dictum by the Court to support the proposition that the new value exception is still viable.

The Court, however, continued to limit the new value exception. The Court stated that the partners' exclusive opportunity to invest new value into the enterprise in return for equity interest should "be treated as an item of property in its own right." ${ }^{, 97}$ Because the absence of an opportunity for "competing bids or even competing plan proposals ... renders the partners' right a property interest," old equity holders were by definition receiving property on account of their jun-

203 N. LaSalle, 526 U.S. at 439-40.

"The bankruptcy court required a minor modification to the plan but, upon modification, would confirm the plan. See In re 203 N. LaSalle St. P'ship, 190 B.R. at 59495 ("[T] he court finds that the debtor has established that its ... plan complies with all of the applicable requirements of Section 1129 .... Upon modification ..., the court will enter an order of confirmation.").

${ }_{92}$ See Bank of Am. Nat'l Trust \& Savs. Ass'n v. 203 N. LaSalle St. P'ship (In re 203 N. LaSalle St. P'ship), 126 F.3d 955, 958 (7th Cir. 1997) (affirming the district court, which had affirmed the bankruptcy court's decision to confirm the plan).

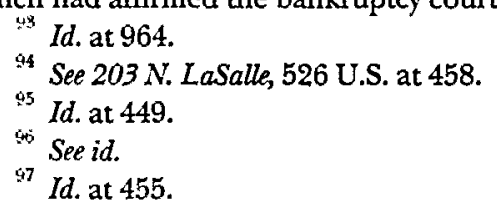


ior interest in the Debtor. ${ }^{98}$ Such a plan violates $\$ 1129$ (b) (2) (B) (ii), which prohibits junior claimants from receiving or retaining any property on account of their junior claim or interest. ${ }^{99}$ Thus, the Court held that "assuming a new value corollary, ... plans providing junior interest holders with exclusive opportunities free from competition and without benefit of market valuation fall within the prohibition of $\$ 1129$ (b) (2) (B) (ii)."100

The Court suggested that a new value plan would be confirmed if there were some assurance that the price that old equity holders bid to retain ownership was "the best obtainable." 101 The Court felt that the only acceptable method of guaranteeing that the equity interest was purchased at the best obtainable price was "market valuation. ${ }^{102}$

\section{New VAlue Plans AFter 203 N. LaSalle}

Debtors who file new value plans, and bankruptcy courts that must determine whether to confirm such plans, have been left with little guidance on how to ensure that new value plans will conform with $\S 1129$ (b) (2) (B) (ii). While new value plans must eliminate the exclusive opportunity of old equity holders, the $203 \mathrm{~N}$. LaSalle Court merely stated that "[w] hether a market test would require an opportunity to offer competing plans or would be satisfied by a right to bid for the same interest sought by old equity, is a question we do not decide here." ${ }^{\text {103 }}$ Thus, the Court suggested two possibilities: (1) giving other parties an opportunity to propose competing plans, or (2) granting other parties the right to bid for the equity interest. ${ }^{104}$ In choosing be-

98 Id. at 456.

99 11 U.S.C. $\$ 1129$ (b) (2)(B) (ii) (1994) ("[T]he holder of any claim or interest that is junior to the claims of [a class of unsecured claims] will not receive or retain under the plan an account of such junior claim or interest in any property.").

${ }^{100} 203$ N. LaSalle, 526 U.S. 458. The Court's holding follows the suggestion of many commentators on how to correct defects in the new value exception. See, e.g., Richard L. Epling, Claims $\mathcal{F}^{3}$ Opinions, an Exchange of Views: The New Value Exception: Is There a Practical, Workable Solution?, 8 BANkR. DEV. J. 335, 347 (1991) (proposing that a possible solution would be to "require exclusivity to end upon the mere filing of a new value plan"); Markell, supra note 28, at 118-19 (calling for elimination of exclusivity).

101203 N. LaSalle, 526 U.S. at 456.

${ }^{102}$ See id. at 458 (stating that some form of market valuation is needed to "test the adequacy of an old equity holder's proposed contribution").

${ }^{109} \mathrm{Id}$.

104 Other possibilities may satisfy the 203 N. LaSalle Court. This Comment will not address those possibilities because they are not as significant. For example, competing new value plans where each plan allows for competitive bidding clearly would satisfy the $203 \mathrm{~N}$. LaSalle Court. Unless required by the courts, however, this possibility will 
tween these two possibilities, the bankruptcy court and the debtor must examine which option is consistent with bankruptcy law and which option provides the "best obtainable" price. ${ }^{105}$

\section{A. What Options Are Available Under Chapter 11?}

The two methods suggested by $203 \mathrm{~N}$. LaSalle, granting other parties the opportunity to propose competing plans or granting such parties the right to bid for equity interest, are both available under the Code. ${ }^{\text {liti }}$

Granting other parties the opportunity to propose competing plans, the competing plans option, is possible under the Code. The debtor can wait until the 120-day exclusivity period expires to propose its new value plan. This will allow other parties the opportunity to propose their own plans. Similarly, a plan proposed by the debtor within the exclusivity period can request the waiver or elimination of the exclusivity period. ${ }^{107}$ The debtor can make such a proposal in its new value plan because the Code only requires that a new value plan satisfy the requirements of $\$ 1129$ (a) and (b), with the exception of $\$ 1129$ (a) (8). Nowhere in those sections is a debtor limited in a request to waive the exclusivity period. Finally, $\$ 1121$ (d) allows the court, for cause, to terminate the exclusivity period and allow other parties in interest to file a plan. ${ }^{108}$ This allows any creditor to propose

never occur because a party that has gone through the expense of drafting a confirmable plan would want to retain as much of the plan's benefit as possible. Allowing other parties to bid could undermine that goal. As another possibility, the debtor-inpossession could waive the 120-day exclusivity period. See Alexander F. Watson, Note, Left for Dead?: The Supreme Court's Treatment of the New Value Exception in Bank of America National Trust \& Savings Association v. 203 North LaSalle Street Partnership, 78 N.C. L. REv. 1190, 1222-23 (2000) (arguing that waiver of the exclusivity period is a practical proposal for conformance with $203 \mathrm{~N}$. LaSalle since it requires the least effort from the debtor and would not require amendment of the Code). That possibility is remote since it is strategically unsound. It would be more strategic for the debtor to wait until the 120-day exclusivity period is over to propose its new value plan or wait until there is no possibility of a consensual new value plan before waiving exclusivity.

2115203 N. LaSalle, 526 U.S. at 456.

Ini There is some debate among commentators on whether there needs to be actual competing plans or bids, or merely opportunities to propose plans or to make those bids. See Watson, supra note 104, at 1221 (discussing the uncertainties involved in determining market value in actual practice). This Comment will analyze the more difficult possibility: that other parties will actually take advantage of their opportunity or right to propose competing plans or make competing bids.

${ }^{17 T}$ Fairness, though, will likely require the bankruptcy court to grant time extensions to other parties to formulate their own plans since the debtor had 120 uninterrupted days.

11 U.S.C. $\$ 1121$ (d) (1994). 
its own plan comprising its own classifications of creditors and treatment of each creditor or interest holder. ${ }^{109}$ Such plans must still be confirmable.

The major problem with the competing plans option is that the bankruptcy judge will be forced to choose one of several confirmable plans. There is no clear guidance in the Code or case law to help a judge determine which plan to confirm. ${ }^{110}$ In addition, the plans may be so dramatically different that other creditors or the judge are forced to "compare apples and oranges." "111 Furthermore, whenever a debtor gives up exclusivity, it potentially "open[s] the way for a liquidation plan to be filed by a secured creditor."112 This penalizes the unsecured creditors, who will receive nothing if the assets are liquidated in cases involving undersecured creditors.

The statutory basis for granting other parties the right to credit bid, the competitive bids option, is also consistent with the Code. Nothing in $\S 1129$ (a) or (b) prevents a debtor from granting other parties the right to credit bid on the equity interest on terms dictated by the debtor. Furthermore, the bankruptcy court is empowered to "issue any order, process, or judgment that is necessary or appropriate to carry out the provisions of this [Act]."113 Bankruptcy courts have historically used this power to allow third-party bidders to come into the reorganization process at the last moment, paying a higher cash price but maintaining all other obligations. ${ }^{114}$

Under the competing bids option, once a debtor proposes a new value plan, any party can accept the debtor's plan and receive the equity interest in the reorganized company by agreeing to pay creditors more than the debtor had proposed. The bankruptcy court will confirm the debtor's plan if no party is willing to accept the plan and pay a higher amount to the creditors. A major benefit of this option is

${ }^{109}$ See id. $\$ \S 1122-1123$ (setting forth the requirements for classification of claims and for contents of a plan of reorganization).

${ }^{110}$ See id. $\$ 1129$ (c) (providing that if there is more than one plan, "the court shall consider the preferences of creditors and equity security holders in determining which plan to confirm"); ABI Real Estate Comm., A Rouindtable Discussion: Supreme Court Decision 203 N. LaSalle St. Partnership, 7 AM. BANkR. INST. L. REv. 389, 404 (1999) (comments of Professor Robert M. Zinman) (arguing that there is no statutory guidance for the judge to follow in choosing a plan).

111 Epling, supra note 100, at 348.

112 Thomas J. Salerno, Last in Line: The Second Circuit Rejects the Viability of the "New Value Exception" to the Absolute Priority Rule, 1998 ABI JNL LEXIS 121, at *7 (June 1998).

113 11 U.S.C. $\$ 105$ (a) (1994).

114 Interview with Kathryn Heidt, Professor of Law, University of Pittsburgh Law School, in Philadelphia, Pa. (Mar. 9, 2000). 
that the bankruptcy judge will not have to make a choice among several confirmable plans.

The most significant problem with the competing bids option is the lack of a determination of what procedures are needed or required by $203 \mathrm{~N}$. LaSalle to ensure proper market valuation. $203 \mathrm{~N}$. LaSalle does not provide such procedures. Several procedures, however, are clearly needed to ensure the fairness of an auction. One such procedure is the requirement of commercially reasonable advertisement and promotion of the bidding process. Other issues regarding applicable procedures are also unresolved. For example, should secured creditors be able to make credit bids? A credit bid means that a creditor could bid up to the amount of her claims and, if she wins, she could keep the property without having to pay additional consideration. ${ }^{115}$ While some commentators have called for granting secured creditors the right to make credit bids, ${ }^{116}$ lower courts that have examined the issue have rejected that approach. ${ }^{117}$ It is clear that this problem will result in future litigation.

Both the competing plans option and the competing bids option will result in an infusion of new value for the reorganized firm. ${ }^{118}$ This

"15. See LINN M. LOPUCKI \& ELIZABETH WARREN, SECURED CREDIT: A SYSTEMS APPROACH 85-87 (2d ed. 1998) (explaining credit bidding at judicial sales of a creditor's collateral; noting that the credit bid is based on the fact that the amount paid for the property over and above the expenses of sale and up to the amount of the secured debt goes to the creditor).

Ifi" See Epling, supra note 100, at 348 (arguing that a process where "[o]ld creditors (but not third parties who have bought their claims) may credit bid up to the value of cash or new debt that they will receive under the plan" would solve some of the problems with new value plans); Markell, supra note 28, at 121-23 (suggesting that credit bids would check owner underbids and protect creditors from debtors taking advantage of low valuation).

Furthermore, in situations where a chapter 11 plan contains a proposal to sell a creditor's collateral, "[t] he right to credit bid at the sale of the collateral is one of the rights normally afforded by the Bankruptcy Code to secured creditors." Michael E. Rubinger \& Gary W. Marsh, Claim and Opinion: "Sale of Collateral" Plans Which Deny a Nonrecourse Undersecured Creditor the Right to Credit Bid: Pine Gate Revisited, 10 BANKR. DEV.J. 265, 265 (1994). $203 \mathrm{~N}$. LaSalle is distinguishable, however, because the debtor was not seeking to sell the collateral but to retain equity in the partnership that owns the collateral. Furthermore, there is no right to a credit bid if the secured creditor can make an 11 U.S.C. $\$ 1111$ (b) (2) election. See Rubinger \& Marsh, supra, at 271-73. The creditor in this case could and did make the election. See 203 N. LaSalle, 526 U.S. at 439.

${ }^{117}$ See, e.g., In re Hickey Props., Ltd., 181 B.R. 171 (Bankr. D. Vt. 1995) (holding that secured creditors cannot credit bid because they have security interests only in the debtor's collateral, not in the debtor's equity interest).

${ }^{11 \times}$ Thus, this Comment does not fail one of the many criticisms of new value plans leveled by Professors Carlson and Williams. See David Gray Carlson \& Jack F. Williams, 
new cash will be used by the company to help in its reorganization, including the repayment of unsecured creditors. Since both options are consistent with the Code ${ }^{119}$ and will result in new cash that will be used in part to repay unsecured creditors, the court should choose the option that will result in the best obtainable price.

\section{B. Which Options Will Result in The Best Price Obtainable?}

\section{Using Law \& Economics to Evaluate the Two Options}

When the $203 \mathrm{~N}$. LaSalle Court called for a market valuation to test the fairness of the equity holder's bid, the Court assumed that only a market valuation was sufficient to ensure fairness. ${ }^{120}$ The Court has previously recognized that market valuation requires a price set in market conditions. ${ }^{121}$ Thus, the bankruptcy court must determine which option most closely satisfies the requirements of market valuation. When evaluating market conditions and determining fair market price, the law and economics approach, and in this case the branch of law and economics dealing with auctions, provides a clear and precise methodology.

\section{a. Why Use Auction Theory?}

Auction theory is appropriate to use in analyzing the two options because the process of competing plans and, especially, the process of competing bids, greatly resemble an auction. ${ }^{122}$ The analytical similarities between auctions and both options suggest that auction theory

The Truth About the New Value Exception to Bankruptcy's Absolute Priority Rule, 21 CARDOzo L. REv. 1303, 1307 (2000) (arguing that most commentators have failed to examine who receives the new value).

${ }^{119}$ This Comment assumes that the new value plan(s) produced under either option satisfy all other requirements in the Code. For an extensive discussion on the new value exception including whether requirements such as necessity and substantiality were superseded by $203 \mathrm{~N}$. LaSalle, see Kevin T. Lantry \& Jeffrey C. Krause, The New Value Exception After 203 N. LaSalle (presented at the Financial Lawyers Conference in Los Angeles, Cal. on Nov. 4, 1999) (unpublished manuscript, on file with the author).

${ }^{120}$ See supra notes 100-01 and accompanying text (reciting the logic of the $203 \mathrm{~N}$. LaSalle Court's holding).

${ }^{121}$ See BFP v. Resolution Trust Corp. ex rel. Imperial Fed. Sav. Ass'n, 511 U.S. 531, 538 (1994) (arguing that fair market price requires a price set by market conditions).

${ }^{122}$ Commentators have noted this resemblance before. See, e.g., Markell, supra note 28, at 107-11 (arguing that an auction is analogous to the reorganization process and that auction theory supports participation by owners in the reorganization process). 
may help us to understand how the debtor, creditors, and third parties would behave under either process. Auction theory can also assist in determining the optimal strategy for each party and the maximum price that each party would bid for the property. Finally, auction theory may also highlight how the parties can act opportunistically under each option, and thus alert us to those areas of each process where antiabuse provisions may be needed.

While there are differences between auctions and either reorganization process, it is still valid to apply auction theory. The two distinct differences between typical auctions and the reorganization process are: (1) auctions tend to occur at one sitting while reorganizations occur over a very long time period; and (2) bidders pay for auctioned property with cash while reorganizations allow plan proponents to pay with cash or cash equivalents. ${ }^{123}$ Both of these differences, however, merely allow sellers in reorganizations to achieve higher sale prices, which benefits the creditors. The longer time period and the ability to use cash equivalents to bid for property increases the number of available bidders. The reasons for this are that more bidders can find out about the reorganization process and bidders who do not have the available cash to bid for the property would not be excluded. The greater number of bidders tends to lead to a higher sale price. ${ }^{124}$ The only technical difficulty in applying auction theory to the competing plans option is that the various plans must be reduced to their net present value.

\section{b. The Theory of Auctions}

Auctions come in four basic forms: the ascending-bid auction, the descending-bid auction, the first-price sealed bid auction, and the second-price sealed bid auction. ${ }^{25}$ In the ascending-bid auction, the most common type of auction, the bids gradually increase in value until the highest bidder wins the auction. ${ }^{126}$ In a descending-bid auction,

${ }^{122}$ See id. at 108 (noting the differences between auctions and the reorganization process).

${ }^{1: 24}$ For a discussion on why more bidders lead to higher prices, see Paul Klemperer, Aution Theory: A Guide to the Literature, 13 J. ECON. SuRvs. 227, 239 (1999). The difference in the bid price can be dramatic. See Markell, supra note 28, at $110 \mathrm{n} .244$ (collecting cases in which the price of a debtor's assets increased when additional bidders became involved in the process).

12 See Klemperer, supra note 124, at 229 (identifying the standard auction types).

12" See id. (describing an ascending-bid auction). In one form of this auction, the Japanese auction, bidders who drop out are not allowed back into the bidding process and bidders cannot make a preemptive "jump bid." Id. 
the auctioneer begins with a very high price and gradually lowers the price. The first bidder to agree to a price wins and pays that price. ${ }^{127}$ In a first-price sealed bid auction, each bidder independently submits a single bid without seeing the bids of others, and the highest bidder wins and pays the price of her bid. ${ }^{128}$ In the second-price sealed bid auction, each bidder independently submits a bid and the highest bidder wins. In this type of auction, however, the bidder pays the price of the second-highest bid. ${ }^{129}$

This Comment will only deal with the ascending-bid auction since it is the type of auction that is most familiar to the public and it will likely be used in actual competing bids or plans. ${ }^{130}$ In an ascending-

${ }^{127}$ See id. (describing a descending-price auction).

128 See id. (describing a first-price sealed bid auction).

129 See id. (describing a second-price sealed bid auction).

${ }^{130}$ While there are generally four basic types of auctions, from an economic point of view, there are only two types of auctions: a first-price bid auction and a secondprice bid auction. See id. at 230 (explaining why some of the auctions are strategically the same). The reason is that the optimal strategy for an ascending-bid auction and a second-price sealed bid auction is the same. See id. (noting that telling the truth about your valuation is the dominant strategy). In an ascending-bid auction, the optimal strategy is to stay in the auction until the price reaches your value. Id. Assuming that you have the highest valuation of the property, you will end up paying the price equal to the value of the second-highest bidder. This is the same result as a second-price bid auction. Id. (noting that in an ascending auction, "the ... person with the highest value will win at a price equal to the value of the second-highest bidder" for these two types of auctions). Of course, this analysis depends upon there being a single auction and each bidder having private valuations. Id. A similar analysis applies to the descending-bid auction and the first-price sealed auction. The optimal strategy in a descending-bid auction is to bid when the price reaches your private valuation of the property. If you have the highest valuation, you would be the first to bid and you would win with your first bid. The same result occurs in a first-price sealed bid auction. The only difference between the first-price and second-price bid auctions is that the latter type allows for many prices while the former type restricts the bidder to one price. From this brief analysis, it is clear that the second-price auction is more advantageous to the buyer because the buyer can gain the extra utility associated with the difference between her valuation and the valuation of the second highest bidder. Thus, it seems strange that sellers would settle upon the ascending-bid auction. A possible answer is that the sellers may seek to attract more purchasers who are familiar with only the ascending-bid auction. The additional bidders may lead to a higher price than the seller could achieve with a descending-bid auction. See id. at 239 (stating that studies show that additional bidders create more value to a seller in an ascending-bid auction than any realistically designed auction without the additional bidders). Finally, under some conditions, the ascending-bid auction is the optimal auction for the seller. See id. at 236-37 (noting that ascending-bid auctions lead to higher expected prices than other auctions when the buyers' signals are affiliated). Finally, the Revenue Equivalence Theorem states that where the buyers are risk-neutral, the object goes to the buyer with the highest value, and any bidder with the lowest-feasible bid expects a zero surplus, all types of auctions yield the same revenue to the seller. See id. at 232 (noting that this theorem is the fundamental theorem in auction theory). 
bid auction, a dominant or winning strategy for a bidder is to stay in the auction until the price exceeds the value of the property to her. ${ }^{131}$ This strategy gives the winning bidder the best chance to get the property. ${ }^{132}$

\section{Both Options Limit the Number of Buyers}

Using statutory analysis and auction theory, it is clear that neither option provides a true market valuation for the price of the equity because both options limit the number of purchasers of the equity interest. The competing plans option is limited to debtors and creditors by $\$ 1121 .^{133}$ The plain language of the Code, therefore, prevents third parties from proposing competing plans. Thus, because fewer people can propose plans, there will be fewer plans for the creditors or bankruptcy judge to choose from.

Similarly, the competing bids option has a limited number of bidders because of asymmetric information and the incentives created by the Internal Revenue Code, specifically, I.R.C. $\$ 382(l)(5)$. There is asymmetric information because a third-party purchaser does not know as much about the company's worth as the debtor or even the creditors would know. Asymmetric information is an additional cost for the third-party purchasers only, so this will reduce the amount that third-party purchasers will bid for the equity interest.

Furthermore, the Internal Revenue Code discourages third parties from bidding. Section $382(l)(5)(\mathrm{A})$ of the Internal Revenue Code penalizes a bidder for a bankrupt company where the bidder was not a prior owner or creditor of the debtor. ${ }^{134}$ Typically, § 382(a)

131 Id. at 230. The optimal strategy for any bidder depends upon whether the auction is dynamic or static, the relative risk-aversion of the seller and bidders, and the budget constraints of the bidders. For a more detailed discussion of the optimal bidding strategy in various types of auctions, see id. at 232-37.

${ }^{112}$ There is, however, a phenomenon called the winner's curse whereby the winning bid often exceeds the true value of the property. See id. at 230 (noting that if the bidder does not take into account other people's bids, the winner can end up paying more than the prize is worth). For a more complete discussion of this phenomenon, including the empirical studies concerning the winner's curse, see RICHARD H. THAIER, THE WINNER'S CURSE: PARADOXES AND ANOMALIES OF ECONOMIC LIFE 50-62 (1992).

${ }^{1.34}$ See 11 U.S.C. $\$ 1121$ (c) (1994) (stating that only a "party in interest, including the debtor, the trustee, a creditor's committee, an equity security holders' committee, a creditor, an equity security holder, or any indenture trustee, may file a plan").

is Section 382(l) (5) (A) provides that:

[I.R.C. $\$ 382$ ] (a) shall not apply to any ownership change if-

(i) the old loss corporation is (immediately before such ownership change) 
limits the amount of net operating losses ("NOLs") that a corporation may use in a taxable year to a fraction of possible net operating losses. ${ }^{135}$ Since NOLs are usually the most valuable assets that the bankrupt company possesses, ${ }^{136}$ this dramatically reduces the incentives for any third party to bid for the reorganized company. A lower number of bidders likely would lead to a lower winning bid. ${ }^{137}$

Both options thus will likely not yield the best price possible for the equity interest due to the limited number of bidders or competing plans. Since both options suffer from the same defect, the bankruptcy court should examine which method would yield the higher price for the equity interest before determining which method to use.

\section{Best Price(s) Under Both Processes}

\section{a. Best Price Under the Competing Bids Option}

Under the competing bids option, old equity holders and any other interested party can bid an amount for the equity interest. To retain that property interest, however, the winning bidder must purchase all of the company since no equity interest remains if the company is liquidated. Auction theory states that a dominant or winning strategy for the equity holders is to bid up to the full value of the equity interest to them. ${ }^{138}$ Bankruptcy law and tax law, however, give the

under the jurisdiction of the court in a title 11 or similar case, and

(ii) the shareholders and creditors of the old loss corporation (determined immediately before such ownership change) own (after such ownership change and as a result of being shareholders or creditors immediately before such change) stock of the new loss corporation (or stock of a controlling corporation if also in bankruptcy) which meets the requirements of section 1504(a)(2) (determined by substituting "50 percent" for " 80 percent" each place it appears).

I.R.C. $\S 382(l)(5)(A)$ (1994). If there is another change in ownership within two years, however, all net operating losses are eliminated. See id. $\$ 382(l)(5)$ (D) (stating exceptions to the $\S 382(l)(5)$ (A) exclusion).

${ }^{135}$ See id. $\$ 382$ (a) (limiting NOLs to an amount equal to the value of the old loss corporation multiplied by the long-term tax-exempt rate). The long-term tax-exempt rate is determined under $\$ 1274$ (d) and is the average market yield on outstanding marketable obligations of the United States with remaining periods to maturity of nine years or more (such as thirty-year Treasury bonds). Id. $\$ 1274$ (d).

${ }^{136}$ See Albert J. Cardinali \& David C. Miller, Tax Aspects of Non-Corporate Single Asset Bankruptcies and Workouts, 1 AM. BANKR. INST. L. REV. 87, 108 (1993) ("Often, the most important tax attributes of individuals and members of a partnership are the net operating losses ('NOL') and NOL carryover.").

${ }^{137}$ For a discussion of the effect of the number of bidders on the bid price, see Klemperer, supra note 124, at 238-40.

${ }^{138}$ See supra note 131 and accompanying text. 
various bidders different property rights that affect their respective bid prices under this dominant strategy. Specifically, old equity holders will bid a higher amount under the competing bids option.

\section{i. Effect of Bankruptcy Law on the Bid Price}

Under the Bankruptcy Code, the reorganization process can be converted easily into a liquidation process. ${ }^{139}$ There is thus a basic bid price for the company-the liquidation value of the debtor's assets. A chapter 11 reorganization plan, however, must give creditors as much under the reorganization plan as each creditor would have received through the liquidation process, ${ }^{140}$ so creditors should have no preference for a chapter 7 plan unless there is a greater delay in receiving their money under chapter 11 than under chapter 7. ${ }^{141}$ Any debtor who seeks to reorganize must believe that the company has some going concern value or else the reorganization plan would not be feasible and, therefore, would not be confirmable. ${ }^{142}$ A bidder that makes a bid for the assets of the debtor in excess of the liquidation price thus expects a positive going concern value. Old equity holders tend to bid a price in excess of the liquidation price because they are less riskaverse than creditors, more optimistic about the business, and more emotionally attached to their company. Since senior creditors know that old equity holders typically value the company more highly than the creditors value the company, the senior claimants can probably afford to bid a higher price than they would normally bid. Thus, senior creditors can capture more of the going concern value of the company under the competitive bidding option than they would have under the old process for confirming new value plans.

${ }^{139}$ See 11 U.S.C. $\$ 1112$ (1994) (explaining the methods by which a chapter 11 reorganization case can be converted into a chapter 7 liquidation case).

14" See ALCES \& HOWARD, supra note 17 , at 656 (stating that $\$ 1129$ (a) (7) requires the bankruptcy court to make a hypothetical evaluation of what each creditor would receive upon liquidation).

${ }^{141}$ See 11 U.S.C. $\$ 1129$ (a) (7) (requiring that reorganization plans be feasible). In response to the objection that the creditor may fear that the reorganized debtor would reduce the value of the assets before becoming insolvent again, see 11 U.S.C. $\$ 1129$ (a) (11), which requires that confirmation of the plan is not likely to be followed by liquidation.

${ }^{142}$ See 11 U.S.C. $\$ 1129$ (a)(11) (requiring, for confirmation of a reorganization plan, that the debtor would not be likely to require additional refinancing or subsequent liquidation). 


\section{ii. Effect of Exclusion of Cancellation-of-Debt Income Under I.R.C. $\S 108$ on the Bid Price}

The Internal Revenue Code also greatly affects the bidding strategy of the various participants. ${ }^{143}$ Normally, discharge of indebtedness or cancellation-of-debt ("COD") is considered income. ${ }^{1+4}$ Thus, if the bank had been able to foreclose or liquidate the assets, the individual partners would have to pay taxes on the sale price of the property plus the remaining unsatisfied debt minus the adjusted basis of the debtor in the property. ${ }^{145}$ The partners in the real estate limited partnership

${ }^{143}$ As the Court noted in $203 \mathrm{~N}$. LaSalle, 526 U.S. at 438 , the debtor entered into bankruptcy because of tax considerations. While $\$ 1129$ (d) allows a court upon challenge to deny confirmation of a plan if there is no business purpose for the plan except tax avoidance, this does not mean that having a tax planning purpose precludes filing for bankruptcy. See Bank of Am. Nat'l Trust \& Savs. Ass'n v. 203 N. LaSalle St. P'ship (In re 203 N. LaSalle St. P'ship), 126 F.3d 955, 969 (7th Cir. 1997) (holding that a desire to avoid a significant tax liability, if legal, is consistent with the bankruptcy code), rev'd, 526 U.S. 434 (1999). For a more detailed discussion of the effect of the Internal Revenue Code on single-asset bankruptcy cases, see Cardinali \& Miller, supra note 163 , at 87 .

${ }^{144}$ See I.R.C. $\$ 108$ (a) (1994) (stating that unless the taxpayer falls into one of four exceptions, discharge of indebtedness is included in gross income). The two most important exceptions are: (1) for cases in chapter 11 of the Code, and (2) if the individual taxpayer is insolvent. $I d . \S 108(\mathrm{a})(1)(\mathrm{A})$-(B).

The exclusion of COD income also applies to limited partnerships. Limited partnerships are business associations that share the tax treatment of partnerships and the limited liability of corporations. See WILLLAM L. CARY \& MELVIN ARON EISENBERG, CASES AND MATERIAIS ON CORPORATIONS 114 (7th ed. 1995) (describing the characteristics of limited partnerships). In a limited partnership, there are "one or more general partners and one or more limited partners." Revised Uniform Limited Partnership Act ["RULPA"] $\$ 101$ (1985). Illinois, where the 203 N. LaSalle Street Partnership was created, adopted the RULPA in 1987. See 805 ILL. COMP. STAT. ANN. 210/100 (West 1993) (adopting RULPA). The general partner has unlimited liability while a limited partner's liability is limited to her interest in the partnership. See RULPA $\$ 303$ ("A limited partner is not liable for the obligations of a limited partnership unless he [or she] is also a general partner, or... he [or she] participates in the control of the business."). The partners are taxed based on their pro rata interest in the partnership. A discharge of indebtedness income, excludable by I.R.C. $\$ 108(a)$, would thus apply at the individual partner level and not the partnership level. See I.R.C. $\$ 702(a)(8)$ (1994) (stating the application of income distribution for the purposes of the federal income tax). It is for this reason that partnerships have been ignored in some analyses of bankruptcy taxation. See, e.g., Patricia A. Cain, From Crane to Tufts: In Search of a Rationale for the Taxation of Nonrecourse Mortgagors, 11 HOFSTRA L. REV. 1, 4 nn.17 \& 19 (1982) (arguing that the partnership aspect could be ignored since "the issues are the same, whether the building was held in a partnership or by the taxpayers individually" because the partnership is a nontaxable entity).

${ }^{145}$ There is no indication concerning the amount of personal insolvency for each partner in $203 \mathrm{~N}$. LaSalle. Thus, this Comment will not address the effect of personal insolvency on the chapter 11 reorganization process. Even if personal insolvency had been mentioned, that topic is best left for another article. 
would have been personally liable for about twenty million dollars if the bank had been able to foreclose. ${ }^{14 \hat{6}}$ Section 108 (a) thus creates an incentive for a taxpayer to file for bankruptcy under chapter 11 instead of another chapter of the Code, and to file for bankruptcy instead of allowing foreclosure because it permits the taxpayer to exclude COD income. ${ }^{147}$

While it seems that only the partners of the debtor, in their individual capacities, could receive the tax benefit of $\S 108(\mathrm{a}),{ }^{148}$ the proposed change to the reorganization process would allow senior creditors to capture some or all of the value of the tax benefit. Since the creditor knows that the exclusion of COD income is valuable to the debtor, the creditor also knows that the debtor is willing to pay a premium for the opportunity to file under chapter 11. Thus, the optimal strategy for the creditor is to bid a higher price than it would normally bid. The creditor, however, is limited by its risk-aversion since the tax benefits are generally worthless to the creditor. ${ }^{149}$ To reduce its risk, the senior creditor could inform the debtor that the senior creditor is willing to bid a higher price for the company's equity interests despite the worthlessness of the tax benefits to the creditor. By making a believable stand and informing the debtor about the creditor's position, the creditor should be able to get a higher bid from the debtor in the debtor's new value plan. ${ }^{150}$

The fact that creditors could capture any of the tax benefits is troublesome because these benefits belong to the individual partners and not to the creditor. Furthermore, the individual partners are merely deferring their tax liability. Any exclusion of COD income requires a commensurate reduction of the tax attributes of the debtor in

${ }^{14 t}$ See In re 203 N. LaSalle St. Ltd. P'ship, 190 B.R. 567, 576 (Bankr. N.D. Ill. 1995) ("The principal of the general partner estimated the collective tax liability of the partners, in the event of foreclosure, at $\$ 20$ million."), affd, 126 F.3d 955 (7th Cir. 1997), rev'd, 526 U.S. 434 (1999). For a detailed discussion on the partnership taxation in the single-asset case, see Cardinali \& Miller, supra note 136, at 100-04.

${ }_{147}$ As a policy matter, I.R.C. $\$ 108(a)$ is improperly distorting the incentives of the bankruptcy system since it will likely encourage more reorganizations under chapter 11 than are socially optimal. The reason is that the tax benefit is a private benefit that reduces the costs of filing a petition for relief under chapter 11.

${ }^{14 \varkappa}$ The reason is because $\$ 108(\mathrm{a})$ applies only to taxpayers who are filing under chapter 11 or who are insolvent-characteristics which creditors generally do not possess.

14: The reason is that the exclusion of discharge of indebtedness applies only to taxpayers who are in chapter 11 or insolvent. See supra note 144.

For a discussion on how to strengthen one's bargaining power by binding oneself to an immutable position, see THOMAS C. SCHELIING, THE STRATEGY OF CONFLICT $221-46(1980)$. 
the order listed in $\S 108$ (b) (2) ${ }^{151}$ These tax attributes include net operating losses of the company ${ }^{152}$ and the basis of the taxpayer in depreciable property that was sold. ${ }^{153}$ Thus, while the taxpayer reduces her present tax liability under $\$ 108(a)$, she will usually pay more taxes in the future. The taxpayer has merely deferred paying her taxes. ${ }^{154}$

Under the new reorganization process, the senior creditors would be receiving the equivalent of a double tax benefit. The senior creditors capture some of the debtor's gain from the tax deferral in the form of additional consideration, and they will not have to reduce any of their future tax attributes since they did not exclude any income under $\S 108(a) .{ }^{155}$ This is a violation of the taxation principles of fairness and equity because the tax deferral provisions of $\S 108$ were meant for bankrupt or insolvent taxpayers, not for creditors like the bank in this case. ${ }^{156}$ Despite violating principles of fairness and equity, the optimal price of the winning bidder must include some of the tax benefits in order to ensure that the secured creditors would not veto the new value plan.

\section{b. Best Price Under the Competing Plans Option}

The same concerns of bankruptcy law and tax law also apply to bidders under the competing plans option. Under the competing

151 I.R.C. $\$ 108$ (b) (1994).

${ }^{152}$ See id. $\$ 108$ (b) (2) (A) (stating that unless the taxpayer elects to reduce the basis first, an excluded COD income will be applied to reducing any NOL for the taxable year of the discharge, and any NOL carryover to such taxable years).

${ }^{153}$ See $i d . \$ 108$ (b) (2)(E) (stating that the taxpayer can apply excluded COD income to reducing the basis of the taxpayer in the property pursuant to $\$ 1017$ once prior tax attributes are reduced). Section 108(b) (5) allows a taxpayer to elect to apply the excluded COD income to reducing the basis before applying the excluded income to reducing the NOLs.

${ }^{154}$ Tax deferral is an active goal for prudent taxpayers due to the time value of money. The time value of money refers to the fact that money paid in the present is worth more than the same amount of money paid in the future since one can invest the money in a bank and get a guaranteed return on the money. The time value of money is the principle behind the use of discounted cash flow and net present value, both of which seek to evaluate the stream of future payments in terms of present-day money. For a more detailed discussion on the time value of money, see BUTLER, supra note 41 , at $183-87$.

${ }^{155}$ The bank would still include the excess consideration in its tax return by reducing the amount of worthless debt it deducted as a trade or business expense. See I.R.C. $\S 162$ (a) (1994 \& Supp. IV 1998) (allowing a taxpayer engaged in a trade or business to deduct all ordinary and necessary expenses incurred).

${ }^{156}$ See id. $\$ 108(\mathrm{a})(\mathrm{I})(\mathrm{A})$-(B) (stating that income exclusion applies only to taxpayers in chapter 11 or to the amount of their insolvency). 
plans option, the undersecured creditor will likely propose liquidation of all the assets, with the proceeds from the collateral going to the secured creditor and the proceeds from the sale of any other assets being divided among the unsecured creditors on a pro rata basis. On the other hand, the debtor will likely propose a series of payments to the secured and unsecured creditors with old equity holders retaining an equity interest. The net present value of the undersecured creditor's plan likely will be the liquidation value. ${ }^{157}$ The net present value of the debtor's plan depends upon how much the debtor is proposing to pay the creditors. This should always exceed the liquidation value, so the price should always exceed the net present value of the undersecured creditor's plan. ${ }^{158}$

Using auction theory, it becomes clear that the price paid for the equity interest under the competing plans option will be the same as the price paid under the competing bids option. In the competing bids option, the debtor's plan is the basic template, and the final confirmed plan pays out at least as much as the debtor's plan. The net present value of the final plan would exceed the net present value of the debtor's new value plan only if a bidder is willing to pay more than the debtor is willing to pay. Since the debtor should have the highest valuation of the company, the winning bidder should be old equity holders under the competing bids option because of the value of the tax deferral. Likewise, under the competing plans option, the winning plan should be the new value plan since that plan must also agree to pay the creditors some portion of the going concern value and the tax deferral benefits to ensure acceptance and deter a different party from making the winning bid. Thus, the optimal strategy for old equity holders is the same in both cases and the price obtained under either method should be the same. Disparity should occur only when the net present values of the competing plans are difficult to compute. The competing bids option does not suffer from this potential problem since the only difference between the new value plan and the final confirmed plan would be cash. The creditors would just vote for the plan that pays the most cash.

${ }^{137}$ See supra Part III.B.3.a.i (noting that the higher price reflects, among other considerations, the debtor's belief that the going concern value of the company is positive). Net present value discounts the value of cash payments to the present value but there is no need for such discounting when there is a liquidation since the cash payments are made in the present.

${ }^{158}$ See supra Part III.B.3.a (noting that the new value plan must give the senior creditor some of the going concern value and tax deferral to ensure approval by senior creditors of the plan). 


\section{Which Option Should the Bankruptcy Court Use?}

Subjecting the two methods to analysis under auction theory has not shown which method is clearly superior. The bankruptcy court could use either method and satisfy the market valuation requirement imposed by the $203 \mathrm{~N}$. LaSalle Court since both methods should yield the same price and impose the same limitations on the number of purchasers. There is a slight advantage, however, for the competing bids option based upon the possibility of a wide disparity in the competing plans. ${ }^{159}$ This would preserve the debtor's exclusive ability to shape the reorganization plan. Creditors, however, would prefer the competing plans option over the competing bids option because it allows them to craft a plan that would benefit them. A bankruptcy judge should allow the debtor to use the competing bids option if the debtor can do so within the exclusivity period, but allow competing plans if the debtor is unable to do so by the end of the exclusivity period. This would preserve the bargaining positions originally established in the Code. In fact, this appears to be what Judge Wedhoff is doing in the 203 N. LaSalle case on remand. ${ }^{160}$

\section{ALTERnatives to NeW VALUE Plans}

Since both methods of conforming a new value plan to satisfy the 203 N. LaSalle Court have serious problems, what other options does the bankruptcy court have to resolve these cases? One option is to prevent single-asset debtors from using the new value exception. There has been some discussion asserting that single-asset real estate debtors should not be allowed to file for bankruptcy because bankruptcy is not the proper vehicle for such cases. ${ }^{161}$ The reason given for

${ }^{159}$ See Epling, supra note 100 (arguing that competing plans can be so different it would be like comparing apples to oranges).

${ }^{160}$ See In re 203 N. LaSalle St. P'Ship, 246 B.R. 325, 328 (Bankr. N.D. Ill. 2000) (noting that both the debtor and the Bank intended to file competing plans).

${ }_{161}$ See, e.g., Little Creek Dev. Co. v. Commonwealth Mortgage Corp., 779 F.2d 1068, 1073 (5th Cir. 1986) (stating that "the protection of the bankruptcy laws is not proper under these circumstances because there is no going concern to preserve, there are no employees to protect, and there is no hope of rehabilitation"); H. Miles Cohn, Good Faith and the Single-Asset Debtor, 62 AM. BANKR. L.J. 131 (1988) (arguing that single-asset debtors should not survive a motion to dismiss a bankruptcy petition for bad faith unless they can show some legitimate purpose such as liquidation or restructuring of debt); Brian S. Katz, Single-Asset Real Estate Cases and the Good Faith Requirement: Why Reluctance to Ask. Whether a Case Belongs in Bankruptcy May Lead to the Incorrect Result, 9 BANKR. DEV. J. 77 (1992) (arguing that most single-asset debtors should not be permitted to file for bankruptcy under chapter 11 because there is no common pool problem 
this proposal is that cases involving single-asset real estate debtors generally involve "a debtor and one creditor," a type of dispute "for which state law remedies were designed." In any case, since there is little if any going concern value associated with single-asset real estate debtors, ${ }^{16}$ the bankruptcy court could just disallow such debtors from using the new value exception since that exception envisioned the need for an infusion of new capital to ensure the success of a going concern. $^{16 / 4}$ A bankruptcy court that follows this line of thinking, however, may preclude single-asset debtors who have legitimate reasons to use the new value exception from using it in order to reorganize its business. This would then effectively destroy the creditors' incentive to negotiate with the debtor. ${ }^{165}$ Furthermore, since single-asset debtors have been allowed into bankruptcy courts before, it is unlikely that the bankruptcy courts can deny such debtors access to bankruptcy relief. Rather, it will likely require congressional action to bar singleasset debtors from the bankruptcy courts.

A better solution would be to discourage single-asset debtors from filing a chapter 11 plan in the first place by amending the Internal Revenue Code. If Congress amended $\S 108(a)$ of the Internal Revenue Code to exclude all gains from a liquidation proceeding under chapter 7 in the same manner as the section excludes COD income under chapter $11,{ }^{166}$ old equity holders would no longer have an incentive to retain an equity interest in the company. Thus, the problems associated with the new value exception, including the problems with using the two methods analyzed in this Comment to satisfy the LaSalle Court, would no longer exist since there would be no need for

and they do not have a going concern value); Salvatore G. Gangemi \& Stephen Bordanaro, Note, The New Value Exception: Square Peg in a Round Hole, I AM. BANKR. INST. L. REv. 173 (1993) (arguing that single asset debtors should not be allowed to use the new value exception).

${ }^{162}$ ALCES \& HOWARD, supra note 17 , at 655.

lis See Ayer, supra note 4, at $1001 \mathrm{n} .202$ (arguing that when the debtor's sole asset is an office building, the going concern value and the liquidation value are the same).

104 See Gangemi \& Bordanaro, supra note 161, at 192 (arguing that the "new value exception's application in single asset reorganizations cannot be supported by the possibility that a reorganization will fail absent an infusion of new value").

See Mark E. MacDonald et al., Confirmation by Cramdown Through the New Value Exception in Single Asset Cases, 1 AM. BANKR. INST. L. REv. 65, 78-84 (1993) (arguing that "ambiguity in valuation creates legitimate zones for negotiations among creditors and interest holders" that would not occur without the new value exception).

See Jack F. Williams, Rethinking Bankrupty and Tax Policy, 3 AM. BANKR. INST. L. REV. 153, 178 (noting that the National Bankruptcy Conference has suggested that "in a bankruptcy case under Chapter 7 or 11, all income attributable to the disposition of the property should be treated as COD income under IRC section 108" and arguing that "[this] proposal should also apply to the extent that a taxpayer is insolvent"). 
the single-asset debtor to file a new value plan. Amending I.R.C. $\$ 108$ would, therefore, provide the cleanest method of dealing with new value plans filed by single-asset debtors.

\section{CONCLUSION}

The new value exception to the absolute priority rule has been a favorite topic for commentators because of the ambiguity around its inception and the Supreme Court's lack of clarity in stating whether the new value exception exists in the current Code. While the Court in $203 \mathrm{~N}$. LaSalle has provided the clearest signal yet that the new value exception still exists, ${ }^{167}$ it has limited the exception further by requiring that insiders lose their exclusive right to contribute new capital in return for equity interests in the reorganized company. Such a requirement will likely lead to one of two methods for a bankruptcy court to confirm a new value plan: by allowing for competing plans, or by allowing any and all parties to bid for the equity interests. There is good news for bankruptcy judges, however, since either method will likely satisfy the $203 \mathrm{~N}$. LaSalle Court. The competitive bidding option is slightly more preferable than the competing plans option since it allows creditors and the bankruptcy court to more easily compare the competing offers. Both methods, however, have problems, including a limit on the number of competing purchasers and the transfer of tax benefits to senior creditors.

The problems with the competitive reorganization process envisioned by the Court in $203 \mathrm{~N}$. LaSalle reflect the need to align bankruptcy and tax policies. More specifically, the Internal Revenue Code should be amended to eliminate the debtor's incentive to file for bankruptcy under chapter 11 . As currently enacted, $\S 108$ of the Internal Revenue Code greatly increases the costs to the debtor of filing under another chapter of the Code. By eliminating the benefits of filing for bankruptcy under chapter 11 , both single-asset real estate debtors and their creditors will benefit. The debtors will retain their tax advantage while the creditors will be able to more quickly cut their losses by receiving their share of the bankrupt company's liquidated assets.

${ }^{167}$ This signal was, however, dictum. See 203 N. LaSalle, 526 U.S. at 449 (finding that there is sufficient ambiguity in the statutory text of $\$ 1129$ (b) to allow for "the possibility apparent in the statutory text, that the absolute priority rule now on the books as [11 U.S.C. $§ 1129$ (b) (2) (B) (ii)] may carry a new value corollary"). 